\title{
Impact of Gender upon the Perception and Auditor's Job Satisfaction
}

\author{
Nasrollah Takhtaei (Corresponding author) \\ Accounting Department, Dezful Branch, Islamic Azad University, Dezful, Iran \\ E-mail: nasrollah_takhtaei@yahoo.com \\ Leila Abbasi Dezfully \\ Accounting Department, Dezful Branch, Islamic Azad University, Dezful, Iran \\ E-mail: leilaabbasi2003@yahoo.com
}

Received: April 24, 2013 Accepted: May 28, 2013 DOI: 10.5296/ijafr.v3i1.3805

\begin{abstract}
The purpose of the present research is to investigate the effects of gender upon the level of job satisfaction of auditing professionals as well as examine if gender leads to differences in their perceptions of work related attributes such as advancement opportunities and relations with supervisors. Questionnaires have been applied as a means to collect required data to test the hypotheses. The dependent variable is gender and independent variable consists of 9 factors including job fulfillment, treatment with supervisors, promotion and advancement opportunities, supervisors, gender discrimination, employee relations with coworkers, workload volume, fringe and benefits, and amount of compensation. The results indicate that there is a significant relationship between gender and all factors regarding independent variable except advancement and promotion opportunities. The results also show that there are differences between male and female auditors in treatment by peers and supervisors and gender discrimination. The results point out the effects of gender on 9 factors of the level of job satisfaction in audit firms.
\end{abstract}

Keywords: Auditing, Job satisfaction, Gender, Job attitude 


\section{Introduction}

There are gender differences among accountants in their attitudes towards their careers. Men were found to be more satisfied with their jobs than women, with most (82\%) men being satisfied or very satisfied compared with just over half $(57 \%)$ of women. females were significantly less satisfied than males with aspects of their careers included: the opportunity for development of skills, the flexibility and control they had over their working hours, interpersonal relationship with other staff (Morley, Bellamy, Jackson, \& O'Neill, 2002). A large wage gap has been observed between male and female public accounting professionals (Cao, Lynn, \& Horn, 1998). Women may find it more difficult than men to balance their dual family and professional responsibilities and may experience greater inter-role stress (Parent, DeAngelis, \& Myers, 1989) Women place less emphasis on status, financial reward and position, and greater emphasis on achieving personal goals and gaining recognition from others (Dann, 1995). Job satisfaction represents the tendency and feeling which individuals have regarding their job (Mosadeghrad, 2003). From view point of Robbins (2001), job satisfaction is attitude and positive perception (Positive feelings) of individuals concerning their job. A person with a high job satisfaction is a person who generally likes their job considerably and they has been able to afford their needs through their job and consequently has positive feelings with regard to it. The organization cannot improve job incentive of employees and cannot increase job satisfaction except for it recognize necessities which are important for individuals. Necessity is a state of disequilibrium or endogenous deficiencies that smooth away an area for strengthening or pressure on behavioral action. Deficiency or inadequacy could have a variety of causes. Nevertheless, the existence of necessity creates individuals incentive so as to do actions which could return the equilibrium and feels satisfaction. With the recognition of needs in a scientific manner, a positive step can be taken with the aim of meeting needs and giving job satisfaction. Alvani (2001) points out that dissatisfaction of organization employees is presented in the form of low return, low profitability, and unrealized goals. In fact, job satisfaction provides conditions which have a positive effect on return with meeting his or her needs thus understanding necessities in organization has priority and using incentive factors of increasing merely salary does not increase employees' job satisfaction. Job satisfaction has a multiple dimensions and complexity concept which has a relationship with the factors including body, social, and spiritual. It means that not only one reason does not provide job satisfaction but also combination of a variety of different factors cause to feel job satisfaction. The importance of auditors' job in presentation of audit's report is clear for everybody which leads to attesting to financial statements. Auditing occupation circumstances are often stressful. Stress has a negative influence on employees inversely and could lead to dissatisfaction and finally could lead to employees leave their job. One of the most important cases of dissatisfaction of inexperienced auditors of work circumstances in audit firms is time limitations for doing favorable duties (Albrecht, Brown, \& Field, 1981; Collins \& Killough, 1989; Mehrani \& Mahdis, 2003). Almer and Single (2007) say that flexible works arrangements help retain, but perhaps not advance, women. One of the most important issues is auditors' job satisfaction in audit firms because, the area of increasing auditors' productivity can be provided through improvement of their job satisfaction and in this manner, audit firms will be successful in 
getting their goals.

Based on aforementioned discussion, the following questions are raised so as to examine auditors' job satisfaction in audit firms: Could it be possible to prevent auditor's turnover with increasing their job satisfaction? Could directors prevent from auditors' exit from audit profession with recognizing factors affecting on auditor's job satisfaction? Could investigation of variables affecting job satisfaction prevent from auditors who may get involved in other jobs? The response to this question and investigation of factors affecting on level of auditors' satisfaction could leads to recognize conditions that provide more proper circumstances for auditors finally and will follow an increasing in job satisfaction for auditors and will decrease auditors' turnover (Moyes, Williams, \& Koch, 2006). The result of this awareness leads to maintain skillful employees and hence leads to the survival of the firm and it would be possible to ensure that great contract will happen. Belkaoui (1989) Highlights that the extent of the auditors' job satisfaction could lead to successful and unsuccessful of audit firms in achieving their goals.

\section{Background and hypotheses development}

Job satisfaction is affected by a variety of social reasons and has different levels. Factors affecting job satisfaction in organization is in relation with variables such as age, training level, gender, working environment, work experience years, individual skills, job skills, education levels, managerial methods of organization and these variables have been investigated by researchers in different groups and organizations. In this study, the effect of gender on auditors' job attitude has been investigated. Job characteristics investigated including 9 factors such as job fulfillment, treatment by peers and supervisors, promotion and advancement opportunities, supervisors, gender discrimination, employee relations with coworkers, amount of compensation, fringe benefits and amount of workload that are based on Spector's (1985) perspective and has presented in report regarding job satisfaction survey and Moyes, et al., (2006) has applied these proxies in his study and these factors have been presented as indicators of job's satisfaction and attitude in most of the contexts of management science and organizational and incentives psychology. Do auditors of men and women have different perspectives in relation to their job? Are social and working conditions of men and women are the same? Do job satisfaction factors have the same definitions from the men and women perspectives? Do women have possibility of advancement the same as men? In the study carried out by Taylor (1999) in Australia, the effect of gender on job satisfaction levels has been indicated and study carried out by Larkin (1990) resulted in that gender does not have any effect on level of auditors' job satisfaction, Ang et al., (1993) confirm that alone gender does not have an influence on level of auditors' job satisfaction in another study. Gregson (1990) rejects the effect of gender on job satisfaction of auditors working in audit firms in U.S directly or even indirectly. Albrecht, et al., (1981) concluded that working environments of audit firms are more satisfied for men using investigating 27 proxies of job satisfaction. Furthermore, existing evidence with regard to job satisfaction of men and women is not satisfied in the opinion of many researchers and it could not be included that even if job level were fixed, women based on their gender characteristics compared with men are more satisfied and even if there were any difference, there are not 


\section{Mll Macrothink}

International Journal of Accounting and Financial Reporting ISSN 2162-3082 2013, Vol. 3, No. 1

enough confidence concerning its concept (Abraham, 1997). In other words, other studies also have emphasized on effect of gender and attitude difference of men and women in relation to job characteristics. For example, Oskamp and Costanzo (1993) point out that women give priority to have satisfied colleagues more than men whereas men give priority to consultative opportunities with others and their effects on important decisions more than women. Therefore, it seems that a variety of different jobs, satisfy men and women with different degree. On the other hand, women feel more satisfaction in situations that are less competitive and are more cooperative (Lussier, Meskimen, \& Kinskey, 1997). Although the promotion degree and job security of men and women were the same based on ranking factors creating job satisfaction by Beutell and Brenner (1986), the rank 3 and 4 were given to the respect and gracious circumstances women by in the next process despite the fact that these ranks for men were gaining more revenue and attaining higher executive responsibilities. Professional auditors are main and principal employees of audit firms in order to continue their working and survival. Audit firms spend a great deal of money so that employ and educate their auditors. In recent years, women presence in working circumstances has intensified strongly which has been dominated by men for years. Whereas most of them consistent with men's requirements. Inattention to differences in attitude between men and women leads to auditor's women dissatisfaction and giving up their audit's firms. Auditor women exit from firms' high positions has a great negative influence on the other auditor's women at the same level and even at lower organizational levels which we simply cannot neglect from its importance (Mosadeghrad, 2003). In addition, it is required to spend a lot of time for training replacement newcomer employee entry to do their job and also putting organization's trust in newcomer and however newcomer's confidence in organization. Confidence and recognizing senior employees for directors and supervisor is vital that it take a long time with regard to newcomer auditors (Morley, et al., 2002). Generally, with measurement of auditors' satisfaction degree for keeping on working with related audit firms could predict continuing being colleague or resignation. In other studies, the way of relationship between auditors' job satisfaction and their incentive for continuing being colleague with audit firms has been examined. Studies carried out in the area of behaviors science point out that being high in auditors' job satisfaction resulted in increasing their incentive for continuing being colleague with organization (Arnold \& Feldman, 1982; Porter \& Steers, 1973). This relationship has been meaningful in the studies carried out by auditors (Dole \& Schroeder, 2001; Harrell \& Stahl, 1984; Rhode, Sorensen, \& Lawler III, 1977). Identifying basic factors of auditors' job satisfaction in audit firms and also employers and directors awareness with regard to attitudinal differences of men and women could help them in keeping their auditors and providing proper environmental conditions. According to above-mentioned and prior research, present study hypotheses are as follows:

H1: there is a significant relationship between gender and job's attitude measured by nine variables including job fulfillment, treatment by peers and supervisors, promotion and advancement opportunities, relationship with supervisors, feeling of gender discrimination, employee relations with coworkers, amount of workload, fringe benefits, and amount of compensation. 
H2: there is a different in job's attitude between men and women.

\section{Research Methodology}

Following the Moyes, et al., (2006), as with other studies in order to investigate the existence of difference in attitude of auditor's men and women, Moyes's (2006) questionnaire has been applied in this study. Questionnaire mentioned includes 48 questions that 17 questions regarding job fulfillment, 5 questions regarding treatment by peers and supervisors, 3 questions regarding promotion and advancement opportunities, 3 questions regarding supervisors, 7 questions regarding gender discrimination, 5 questions regarding employee relations with coworkers, 3 questions regarding fringe benefits and amount of workload and 2 questions regarding amount of compensation. In the questionnaire mentioned, we have used Likert's Scale and degrees of privileging from highly agree, agree, disagree, and highly disagree has been priced. The degree of questionnaire reliability was calculated by use of coefficient of Cronbach's Alpha which calculated coefficient 0.831 indicating high correlation of questions. In this study, 300 questionnaire were distributed that based on received responses, some of the questionnaire were not useable and thus 269 out of 300 valid questionnaires were completed and extracted. The selection of variables is based on theoretical perspective of study carried out by (Moyes, et al., 2006).

In order to test the hypotheses and to investigate the relationship between gender and level of job satisfaction, chi-square and in order to investigate the existence of job's attitude difference between men and women, independent sample test has been used. Since number of research data is more than 30 , hence being normality of variables distribution is acceptable.

\section{1. Dependent variable}

Job satisfaction is defined as dependent variable that is measured using 9 proxies including; 1) job fulfillment, 2) treatment by peers and supervisors, 3) promotion and advancement opportunities, 4) supervisors, 5) gender discrimination, 6) employee relations with coworkers, 7) amount of compensation, 8) fringe benefits, and 9) amount of workload.

\section{2. Independent variable: gender}

\section{Empirical Results}

To investigate whether there is a statistically significant relationship between gender and job's attitude measured by nine variables including job fulfillment, treatment by peers and supervisors, promotion and advancement opportunities, relationship with supervisors, feeling of gender discrimination, employee relations with coworkers, amount of workload, fringe benefits, and amount of compensation or not, a chi-square statistic was used. Table 4.1 shows the chi-square results and indicates that there is as significant relationship between gender and eight variables of job's attitude composing job fulfillment $(\chi 2=37.736, p<0.001)$, treatment by peers and supervisors $(\chi 2=31.659, \mathrm{p}<0.001)$, relationship with supervisors $\left(\chi^{2}\right.$ $=28.819, \mathrm{p}<0.001)$, feeling of gender discrimination $(\chi 2=25.326, \mathrm{p}<0.001)$, relations with other colleagues $(\chi 2=26.696, p<0.001)$, amount of workload $(\chi 2=74.865, p<0.001)$, fringe benefits $(\chi 2=11.438, p<0.001)$, and amount of compensation $(\chi 2=29.655, p<0.001)$, and 


\section{Macrothink}

International Journal of Accounting and Financial Reporting

ISSN 2162-3082 2013, Vol. 3, No. 1

hence statistically the relationship between gender and eight aforementioned variables is significant, but there is no relationship between gender and promotion and advancement opportunities $(\chi 2=15.719, \mathrm{p}>0.001)$.

Table 4.1 Chi-square Analysis of job's attitude of auditors of male and female

\begin{tabular}{|c|c|c|}
\hline variables & $\chi^{2}$ & P-value \\
\hline There is a significant relationship between gender and job fulfillment. & 37.736 & 0.000 \\
\hline There is a significant relationship between gender and treatment by peers and supervisors. & 31.659 & 0.000 \\
\hline There is not a significant relationship between gender and promotion and advancement opportunities. & 15.719 & 0.008 \\
\hline There is significant relationship between gender and relationship with supervisors. & 28.819 & 0.000 \\
\hline There is significant relationship between gender and feeling of gender discrimination. & 25.326 & 0.000 \\
\hline There is significant relationship between gender and employee relations with coworkers. & 26.696 & 0.000 \\
\hline There is significant relationship between respondent's gender and amount of workload. & 74.865 & 0.000 \\
\hline There is a significant relationship between gender and fringe benefits. & 11.438 & 0.000 \\
\hline There is significant relationship between gender and amount of compensation. & 29.655 & 0.000 \\
\hline
\end{tabular}

To investigate if there is a different in job's attitude between auditor's men and women or not, an independent sample test was applied. Table 4.2 shows the independent sample test results and indicates that job's attitude of males were significantly different from females in reference to variables comprising treatment by peers and supervisors $(\mathrm{p}<0.05$ and equals to $0.00)$ and gender discrimination $(\mathrm{p}<0.05$ and equals to 0.00$)$. Inspection of the two group means indicates that the average treatment by peers and supervisors for male (11.30) and average gender discrimination for male (17.74) is higher than average treatment by peers and supervisors for female (10.14) and average gender discrimination for females (17.04). The differences between two means are 1.16 and 0.70 respectively. Males did not differ significantly from females on variables comprising job fulfillment $(\mathrm{p}=0.31)$, promotion and advancement opportunities (0.37), relationship with supervisors (0.48), employee relations with coworkers (0.41), amount of workload (0.64), fringe benefits (0.13), and amount of compensation (0.65). 


\section{Macrothink \\ International Journal of Accounting and Financial Reporting \\ ISSN 2162-3082 2013, Vol. 3, No. 1}

Table 4.2 Comparison job's attitude of auditors of male and female

\begin{tabular}{|c|c|c|c|c|c|c|}
\hline variables & $n$ & Mean & $S D$ & $t$ & $d f$ & $p$ \\
\hline Job fulfillment & & & & 1.03 & 235 & 0.31 \\
\hline Male & 165 & 44.21 & 2.4 & & & \\
\hline Female & 72 & 43.86 & 2.48 & & & \\
\hline Treatment by peers and supervisors & & & & 5.71 & 256 & 0.00 \\
\hline Male & 177 & 11.3 & 1.59 & & & \\
\hline Female & 81 & 10.14 & 1.36 & & & \\
\hline Promotion and advancement opportunities & & & & -0.89 & 267 & 0.38 \\
\hline Male & 180 & 8.27 & 1.25 & & & \\
\hline Female & 89 & 8.4 & 0.9 & & & \\
\hline Supervisors & & & & 0.71 & 267 & 0.48 \\
\hline Male & 180 & 7.98 & 1.15 & & & \\
\hline Female & 89 & 7.89 & 0.78 & & & \\
\hline Gender discrimination & & & & 3.65 & 245 & 0.00 \\
\hline Male & 173 & 17.74 & 1.57 & & & \\
\hline Female & 74 & 17.04 & 0.78 & & & \\
\hline Employee relations with coworkers & & & & 0.83 & 257 & 0.41 \\
\hline Male & 178 & 13.62 & 1.04 & & & \\
\hline Female & 81 & 13.51 & 1.09 & & & \\
\hline Amount of Workload & & & & 1.86 & 267 & 0.06 \\
\hline Male & 180 & 7.46 & 1.25 & & & \\
\hline Female & 89 & 7.15 & 1.35 & & & \\
\hline Fringe benefits & & & & -1.51 & 267 & 0.13 \\
\hline Male & 180 & 8.04 & 0.59 & & & \\
\hline Female & 89 & 8.17 & 0.73 & & & \\
\hline Amount of compensation & & & & -1.85 & 267 & 0.07 \\
\hline Male & 180 & 5.37 & 0.8 & & & \\
\hline Female & 89 & 5.54 & 0.5 & & & \\
\hline
\end{tabular}

\section{Conclusion}

1. There is a significant relationship between respondent's gender and job fulfillment.

2. There is a significant relationship between respondent's gender and treatment by peers and supervisors.

3. There is not a significant relationship between respondent's gender and promotion and advancement opportunities.

4. There is significant relationship between respondent's gender and relationship with supervisors.

5. There is significant relationship between respondent's gender and feeling of gender discrimination. 
6. There is significant relationship between respondent's gender and employee relations with coworkers.

7. There is significant relationship between respondent's gender and amount of workload.

8. There is a significant relationship between respondent's gender and fringe benefits.

9. There is significant relationship between respondent's gender and amount of compensation.

10. There is an attitude difference between men and women with regard to treatment by peers and supervisors and gender discrimination.

In the examination of relationship between gender and 9 variables which cover job's attitude of individuals, it can be seen that there is no significant relationship between gender and variable namely promotion and advancement opportunities. It is seemed very optimistic that we think that promotion and advancement opportunities is the same for men and women in jobs particularly audit engagements with special working conditions and characteristics and in regard to fringe benefits similarly is done the same. It could be said that many factors can be interfered in this area including whether herself own women are attempting to promote their jobs or based on the historical and traditional role that women are expected to do from their birth by society, conservatism would be continued by them and playing role as a low-ranking employee is good and sufficient for them. There are certain duties for women that they are required to do consistent with formation of gender's identity and social learning. In this attitude, the main duties of women consist of paying attention to children and conduct their home affairs and hence occupation and earning revenue are defined as a second preference for women. This attitude is very much intensifier among their own women than men. Many of the women feel that they are indebted and owed to their families and this attitude causes to feel that the time that they must be accessible to their husbands and children are spending on administrative center and occupation. This attitude is result from social learning and formation of gender's identity and duties of every gender. There are less women's employee than men that enter in challenges of changes and opportunistic behavior in order to promote their jobs and most of them are persuaded with their routine affairs and consistent affairs of administrative and they avoid doing modern and different undertakings. Conservatism and acceptance of consistent jobs are one of women's characteristics in offices and according to the results of similar research, managers also select their subordination's managers among men than women because, men use opportunity to make known their selves.

\section{References}

Abraham, C. (1997). Industrial \& Organizational Soicology. Tehran: Roshd.

Albrecht, W., Brown, S., \& Field, D. (1981). Toward increased job satisfaction of practicing CPAs. Journal of Accountancy, 152(2), 61-66.

Almer, E. D., \& Single, L. E. (2007). Shedding light on the AICPA work/life and women's initiatives research: What does it mean to educators and students? Issues in Accounting Education, 22(1), 67-77. 
Alvani, M. (2001). General Management. Tehran: Ney.

Ang, K. B., Goh, C. T., \& Koh, H. C. (1993). Research Notes, The Impact of Age on the Job Satisfaction of Accountants. Personnel Review, 22(1), 31-39.

Arnold, H. J., \& Feldman, D. C. (1982). A multivariate analysis of the determinants of job turnover. Journal of Applied Psychology, 67(3), 350.

Belkaoui, A. (1989). Behavioral accounting: the research and practical issues: Quorum Books.

Beutell, N. J., \& Brenner, O. C. (1986). Sex differences in work values. Journal of Vocational Behavior, 28(1), 29-41.

Cao, L. T., Lynn, S., \& Horn, B. (1998). The earnings gap between male and female accounting professionals: Empirical evidence and explanations. Advances in Public Interest Accounting, 7, 27-50.

Collins, K. M., \& Killough, L. N. (1989). Managing stress in public accounting. Journal of Accountancy, 167(5), 92-98.

Dann, S. (1995). Gender differences in self-perceived success. Women in Management Review, 10(8), 11-18.

Dole, C., \& Schroeder, R. G. (2001). The impact of various factors on the personality, job satisfaction and turnover intentions of professional accountants. Managerial Auditing Journal, 16(4), 234-245.

Gregson, T. (1990). Communication satisfaction: A path analytic study of accountants affiliated with CPA firms. Behavioral Research in Accounting, 2, 32-49.

Harrell, A. M., \& Stahl, M. J. (1984). McClelland's trichotomy of needs theory and the job satisfaction and work performance of CPA firm professionals. Accounting, Organizations and Society, 9(3), 241-252.

Larkin, J. M. (1990). Does Gender Affect Internal Auditor's Performance? The Woman CPA, 52(2), 20.

Lussier, R. N., Meskimen, C. J., \& Kinskey, J. M. (1997). Management: concepts, applications, skill development: South-Western College Publishing.

Mehrani, S., \& Mahdis, N. (2003). Ethical theory and impact of time budget pressure upon the behavior of independent auditors. The Iranian Accounting and Auditing Review, 32(2), 43-61.

Morley, C., Bellamy, S., Jackson, M., \& O'Neill, M. (2002). Attitudinal barriers to women's career progression in accounting in Australia. Australian Accounting Review, 12(26), 64-72.

Mosadeghrad, A. (2003). Principles of Health Care Administration. Tehran: Dibagaran.

Moyes, G. D., Williams, P. A., \& Koch, B. (2006). The effects of age and gender upon the 


\section{Macrothink}

International Journal of Accounting and Financial Reporting

ISSN 2162-3082 2013, Vol. 3, No. 1

perceptions of accounting professionals concerning their job satisfaction and work-related attributes. Managerial Auditing Journal, 21(5), 536-561.

Oskamp, S., \& Costanzo, M. (1993). Gender issues in contemporary society (Vol. 6): Sage Publications, Inc.

Parent, D., DeAngelis, C., \& Myers, N. (1989). Parity for women CPAs. Journal of Accountancy, 169, 72-76.

Porter, L. W., \& Steers, R. M. (1973). Organizational, work, and personal factors in employee turnover and absenteeism. Psychological bulletin, 80(2), 151.

Rhode, J. G., Sorensen, J. E., \& Lawler III, E. E. (1977). Sources of professional staff turnover in public accounting firms revealed by the exit interview. Accounting, Organizations and Society, 2(2), 165-175.

Robbins, S. P. (2001). Organizational Behavior (14 ed.): Pearson Education India.

Spector, P. E. (1985). Measurement of human service staff satisfaction: Development of the Job Satisfaction Survey. American journal of community psychology, 13(6), 693-713.

Taylor, D. (1999). Managing job satisfaction: data aimed at helping an accounting firm retain its talented professional staff. Australian CPA, 69, 46-47. 